\title{
Mannosylated biodegradable polyethyleneimine for targeted DNA delivery to dendritic cells
}

This article was published in the following Dove Press journal:

International Journal of Nanomedicine

13 June 2012

Number of times this article has been viewed

Xun Sun

Simu Chen

Jianfeng Han

Zhirong Zhang

Key Laboratory of Drug Targeting and Drug Delivery System, Ministry of Education, West China School of Pharmacy, Sichuan University, Chengdu, People's Republic of China

Correspondence: Xun Sun Key Laboratory of Drug Targeting and Drug Delivery System, Ministry of Education, West China School of Pharmacy, Sichuan University, No 17, Block 3, Southern Renmin Road, Chengdu 61004I, People's Republic of China

Tel +862885502307

Email xunsun22@gmail.com
Background: To establish a potential gene-delivery system with the ability to deliver plasmid DNA to dendritic cells (DCs) more efficiently and specifically, we designed and synthesized a low-molecular-weight polyethyleneimine and triethyleneglycol polymer (PEI-TEG) and a series of its mannosylated derivatives.

Methods: PEI-TEG was synthesized from PEI2000 and PEI600 with TEG as the cross-linker. PEI-TEG was then linked to mannose via a phenylisothiocyanate bridge to obtain man-PEITEG conjugates. The DNA conveyance abilities of PEI-TEG, man-PEI-TEG, as well as control PEI25k were evaluated by measuring their zeta potential, particle size, and DNA-binding abilities. The in vitro cytotoxicity, cell uptake, and transfection efficiency of these PEI/DNA complexes were examined on the DC2.4 cell line. Finally, a maturation experiment evaluated the effect of costimulatory molecules CD40, CD80, and CD86 on murine bone marrow-derived DCs (BMDCs) using flow cytometry.

Results: PEI-TEG and man-PEI-TEG were successfully synthesized and were shown to retain the excellent properties of PEI25k for condensing DNA. Compared with PEI-TEG as well as PEI25k, the man-PEI-TEG had less cytotoxicity and performed better in both cellular uptake and transfection assays in vitro. The results of the maturation experiment showed that all the PEI/ DNA complexes induced an adequate upregulation of surface markers for DC maturation.

Conclusion: These results demonstrated that man-PEI-TEG can be employed as a DC-targeting gene-delivery system.

Keywords: dendritic cells, DCs, mannose, polyethyleneimine, PEI, gene delivery

\section{Introduction}

Over the last decade, there has been a lot of interest in DNA vaccines due to their ability to achieve potent immune responses without the limitations of many conventional vaccines. DNA vaccines offer a promising new approach for generating a wide range of desired immunities including cytolytic T lymphocytes (CTL), T helper cells, and antibodies, while being easy to manufacture, easy to administer, and safe. ${ }^{1}$ One of the keys to developing DNA vaccines is the establishment of an efficient and specific gene-delivery system that will allow the expression of antigen protein and subsequent activation of T-cell immunity.

A number of DNA delivery systems have been developed that utilize a variety of materials such as polymers, peptides, and cationic liposomes. ${ }^{2}$ Among these, the cationic polymer polyethyleneimine (PEI), which was introduced by Boussif et $\mathrm{al}^{3}$ has been widely studied due to its ability to deliver DNA with high efficiency. Because of its excellent performance as a vehicle for gene delivery, branched PEI25k has been used 
as a standard reference for other new polymers. However, this system is significantly limited by its cytotoxicity. ${ }^{4}$ Recent reports have demonstrated that, compared with lowmolecular-weight PEI (LMW-PEI, such as PEI2000), highmolecular-weight PEI (HMW-PEI, such as PEI25k) exhibits higher transfection efficiency and higher cytotoxicity. ${ }^{5-7}$ In our previous study, a biodegradable LMW-PEI polymer (PEI-TEG) was synthesized by cross-linking LMW-PEI through biscarbamate linkages. ${ }^{8}$ It was shown that this was a promising and applicable gene-delivery carrier due to its lower cytotoxicity and higher gene transfection efficiency than commercial PEI25k.

Another major drawback of PEI-mediated gene-delivery systems is its nonspecific interaction with cells, which is especially important in DNA vaccine treatments that demand highly efficient delivery of antigen-encoded DNA to specific cells. A key point in the development of DNA vaccines is finding suitable target cells. Dendritic cells (DCs), which are the most effective antigen-presenting cells (APCs) of the immune system, are a key component for the regulation of both innate and adaptive immune responses as well as the maintenance of immunological tolerance. ${ }^{9}$ Due to their unique ability to efficiently present antigens to $T$ cells, many researchers have focused on their application in DNA vaccines in recent years, and there is tremendous potential in developing DNA vaccines that target DCs with a DNA delivery system.

To enhance the specificity of our delivery system to DCs, a specific ligand is required. It has been demonstrated that there is an abundant expression of mannose receptor (MR) on the surface of APCs, including DCs. ${ }^{10}$ The MR has been shown to select ligands carrying terminal sugars such as mannose and $\mathrm{N}$-acetylglucosamine, ${ }^{11}$ and to transport these into cells through receptor-mediated endocytosis, which results in major histocompatibility complex (MHC) presentation and subsequent $\mathrm{T}$ cell activation. ${ }^{12,13}$ This suggests that the mannosylation of a drug- or gene-delivery system may improve their DC specificity and, as expected, some mannosylated proteins have been shown to enhance MHC-I and -II restricted antigen presentation as well as T cell stimulation compared with nonmannosylated proteins. ${ }^{11,14}$ Furthermore, many mannosylated drug or gene-delivery systems such as mannosylated chitosan microspheres, ${ }^{15}$ mannosylated lipopolyplexes, ${ }^{16}$ mannosylated PEI, ${ }^{17,18}$ mannosylated PEI-coupled mesoporous silica nanoparticles, ${ }^{19}$ and mannosylated chitosan-graft-PEI ${ }^{20}$ have been reported to augment transfection efficiency and immunogenicity by targeting the MR on APCs. Therefore, in this study, mannose ligand was employed to provide selective DC targeting for the delivery of a DNA vaccine.
In the current study, a gene-delivery system based on a mannosylated, biodegradable LMW-PEI polymer (manPEI-TEG) was designed and synthesized for the purpose of improving DC specificity, increasing transfection efficiency, and reducing cytotoxicity. Physiochemical properties of the carrier and its complexes prepared with plasmid DNA were analyzed. The in vitro cytotoxicity, transfection efficiency, and DC maturation abilities were also investigated.

\section{Materials and methods Materials}

Branched PEI 25k, branched PEI 2k, 3-(4,5-dimethylthiazole-2-yl)-2,5-diphenyl tetrazolium bromide (MTT), agarose, and HEPES were purchased from Sigma-Aldrich (St Louis, MO). PEI600 (Alfa Aesar, Ward Hill, MA) was used after vacuum drying at $70^{\circ} \mathrm{C}$ for 1 hour. Triethyleneglycol (TEG) was purchased from Kelong (Chengdu, China). The pG14.10(luc2) (4242 bp) plasmid DNA was isolated and purified from DH5- $\alpha$ Escherichia coli using the Qiagen Giga Endo-free plasmid purification kit (Germantown, MD). Cell culture medium RPMI-1640 and fetal bovine serum (FBS) were obtained from Gibco Co (Life Technologies, Grand Island, NY). Luciferase assay system was procured from Promega (Madison, WI). BCA protein assay kit was obtained from KeyGEN. DC2.4 cell line was kindly provided by Dr Ying Wan of Third Military Medical University, China. All the other chemicals and solvents were obtained commercially and used without further purification.

\section{Synthesis and characterization of mannosylated PEI-TEG (man-PEI-TEG)} Synthesis of mannopyranosylphenyl isothiocyanate

Mannopyranosylphenyl isothiocyanate was synthesized according to the methods of Munch et $\mathrm{al}^{21}$ and Shi et $\mathrm{al}^{22}$ Briefly, $180 \mathrm{~mL} \mathrm{Ac} 2 \mathrm{O}$ and $210 \mathrm{~mL} \mathrm{C}_{5} \mathrm{H}_{5} \mathrm{~N}$ were added to a three-necked bottle and cooled to $-5^{\circ} \mathrm{C}$, after which 20 g D-mannose was gradually added. The mixture was stirred for 5 hours at room temperature and then poured into $2 \mathrm{~L}$ of icy water. As a result, a crude acetylated mannose precipitate was obtained. $\mathrm{BF}_{3} \mathrm{Et}_{2} \mathrm{O}$ was added slowly to $11.7 \mathrm{~g}$ of the solution of the crude acetylated mannose precipitate and $8.4 \mathrm{~g} \mathrm{p}$-nitrophenol in $100 \mathrm{~mL} \mathrm{CH}_{2} \mathrm{Cl}_{2}$. After this was stirred at $25^{\circ} \mathrm{C}$ for 24 hours, the solvent was removed and then purified by silica gel chromatography to yield p-nitrophenol-1-acetylated mannose. Then $5.5 \mathrm{~g}$ of the p-nitrophenol-1-acetylated mannose was dissolved in $50 \mathrm{~mL}$ absolute $\mathrm{MeOH}$ and a small amount of $\mathrm{MeONa}$ was added and stirred at room temperature for 1 hour, then cation 
exchange resin was added and this was stirred for another hour. After suction filtration, yellow filtrate (p-nitrophenol1-mannose) was obtained. After this, $10 \% \mathrm{Pd} / \mathrm{C}$ was added to the yellow filtrate and stirred at room temperature under $\mathrm{H}_{2}$ for 12 hours, after which the reaction mixture was filtered through celite. The solvent was removed by concentration in vacuo and then purified by silica gel chromatography to yield p-aminophenol-1-mannose. Following this, $1.56 \mathrm{~mL} \mathrm{CS}_{2}$ and $715 \mu \mathrm{L}$ triethylamine were added to $700 \mu \mathrm{g}$ of the solution of p-aminophenol-1-mannose in $1 \mathrm{~mL}$ EtOH. This was stirred for 30 minutes before being cooled to $0^{\circ} \mathrm{C}$, and 4-dimethylaminopyridine (DAMP) followed by $950 \mu \mathrm{L}$ Boc $2 \mathrm{O}$ were then added to the cooled mixture. The reaction was stirred for another 20 minutes, after which the solvent was evaporated in vacuo and purified by silica gel chromatography to yield mannopyranosylphenyl isothiocyanate.

\section{Synthesis of PEI polymer with triethyleneglycol (TEG) as the cross-linker (PEI-TEG)}

The synthesis method of the PEI derivate with TEG as the crosslinker was presented by Zhao et al. ${ }^{8}$ Briefly, $1.5 \mathrm{~g}$ anhydrous triethyleneglycol (TEG, $10.0 \mathrm{mmol}$ ) was dissolved in $250 \mathrm{~mL}$ anhydrous ethylene dichloride and then $6.04 \mathrm{~g}$ 4-nitrophenyl chloroformate (NPC, $30.0 \mathrm{mmol}$ ) was added. The solution was stirred and $4.15 \mathrm{~mL} \mathrm{EtN}_{3}(30.0 \mathrm{mmol})$ was added. The reaction mixture was stirred at room temperature for 6 hours, and was subsequently washed with saturated $\mathrm{NaCl}$ solution and the organic phase was collected and dried over anhydrous $\mathrm{Na}_{2} \mathrm{SO}_{4}$. After this, the solvent was added dropwise to $20.0 \mathrm{~g}$ of the mixture of PEI600 and PEI2000, which was dissolved in ethylene dichloride, and the weight ratio of PEI600:PEI200 (1:3) employed was optimized in a previous study (data not shown). After stirring for another 16 hours, the solution was evaporated to remove the solvent. The viscous residue was dissolved again in double-distilled water and dialyzed through a cellulose membrane with a molecular weight cut off of 3500 for 5 days, and then, after 2 days of lyophilization, a solid or semisolid yellowish product or albicans product with a high viscosity was collected. This product was PEI-TEG.

\section{Synthesis of man-PEI-TEG conjugates}

The man-PEI-TEG conjugate had mannose linked to PEI via a phenylisothiocyanate bridge using mannopyranosylphenyl isothiocyanate as a coupling reagent, and was synthesized through a thiourea reaction according to the method of Diebold et al. ${ }^{18}$ Briefly, branched PEI-TEG was dissolved in distilled water and mixed with various amounts of mannopyranosylphenyl isothiocyanate in DMSO. The reaction was performed for 1 day at room temperature. Dialysis of the product against $150 \mathrm{mM} \mathrm{NaCl}$ for 2 days and then against double-distilled water for 3 days, followed by lyophilization, yielded the final product. The PEI-TEG to mannopyranosylphenyl isothiocyanate feed ratios of $1: 1$, $2: 1$, and 3:1 were used in order to obtain three mannosylated derivates with different substitution degrees of mannose ligand. These derivates were named man-PEI-TEG-A, manPEI-TEG-B, and man-PEI-TEG-C, respectively (Table 1), or simply $\mathrm{A}, \mathrm{B}$, and $\mathrm{C}$, respectively.

\section{Characterization of man-PEI conjugates}

Nuclear magnetic resonance (NMR) was used to confirm the structure of products. For proton NMR (1H-NMR) experiments, the mannopyranosylphenyl isothiocyanate and PEI derivates were dissolved in $\mathrm{CD}_{3} \mathrm{OD}$ and $\mathrm{D}_{2} \mathrm{O}$ (purchased from Sigma-Aldrich) respectively. The samples were analyzed in a Varian UNITY INOVA 400 NMR Spectrometer (Varian Inc., Palo Alto, CA) at $400 \mathrm{MHz}$.

The molecular weight and polydispersity index (PDI) of the PEI-TEG and man-PEI-TEG conjugates were determined by gel permeation chromatography (GPC) relative to PEG standards (Polymer Labs, Amherst, MA). ${ }^{23}$

Compared to PEI-TEG, the molecular weights of mannosylated PEI-TEG A, B, and C were increasingly affected by an increase in mannose residues. The formula below can be used to calculate the weight ratio of mannose residues in man-PEI-TEG conjugates A, B, and C:

$$
\begin{aligned}
\text { Mannose } \%= & (\text { Mw man-PEI-TEG }- \text { Mw PEI-TEG }) / \\
& \text { Mw man-PEI-TEG } \times 100 \%
\end{aligned}
$$

Table I Characteristics of the PEI-TEG and man-PEI-TEG derivates: feed ratio, weight-average molecular weight (Mw), polydispersity index (PDI), and mannose content

\begin{tabular}{llllll}
\hline Polymers & PEI:mannose (weight ratio) & Mw (kDa) & PDI & Theoretical mannose \% & Experimental mannose \% \\
\hline PEI-TEG & & 26.02 & 1.53 & & $35.0 \%$ \\
A & I:I & 40.05 & 1.94 & $50.0 \%$ & $32.8 \%$ \\
B & $2: I$ & 38.73 & 1.94 & $33.3 \%$ & $24.4 \%$ \\
C & $3: I$ & 34.40 & 1.89 & $25.0 \%$ & \\
\hline
\end{tabular}

Abbreviations: PEI, polyethyleneimine; TEG, triethyleneglycol; PEI-TEG, polyethyleneimine and triethyleneglycol polymer; man-PEI-TEG, mannosylated PEI-TEG; A, manPEI-TEG derivative A; B, man-PEI-TEG derivative B; C, man-PEI-TEG derivative C; Mw, molecular weight; PDI, polydispersity index. 


\section{man-PEI/DNA complex preparation}

The preparation of the man-PEI-TEG/DNA complex was performed according to the delineation published by Kloeckner et al. ${ }^{24}$ DNA plasmid (pGL4.10 (luc2)) was diluted in 5\% glucose solution to a final concentration of $80 \mu \mathrm{g} / \mathrm{mL}$, and the indicated amounts of man-PEI-TEG derivates were also diluted to the same volume with $5 \%$ glucose solution $(\mathrm{pH}$ 4.0). Following this, the DNA solution was added into the PEI solution and was vortexed for 10 seconds, then incubated at room temperature for 20 minutes. To obtain complexes of different carrier: DNA ratios, DNA was condensed by manPEI-TEG derivatives at various mass ratios. In this work, PEI derivatives to DNA ratios were expressed by both weight ratios and N/P ratios, and the following formula can be used to convert the weight ratios to N/P ratios: ${ }^{25}$

\section{$\mathrm{N} / \mathrm{P}=(\mathrm{WPEI} / \mathrm{WDNA})(\mathrm{EWDNA} / \mathrm{EWPEI})$}

where $\mathrm{N}$ is the equivalent of ionizable nitrogen, $\mathrm{P}$ is the equivalent of ionizable phosphorous, $\mathrm{W}$ refers to weight, and EW refers to equivalent weight.

\section{Particle size and zeta potential analysis}

The mean particle size and zeta potential of the DNA/PEI complexes were determined at $25^{\circ} \mathrm{C}$ using photon correlation spectroscopy (PCS) (Zetasizer Nano ZS90; Malvern Instruments Ltd, Worcestershire, UK). Before measurement, the PEI/DNA complexes of N/P ratios ranging from 5:1 to 40:1 were prepared as described above. Each complex sample contained $10 \mu \mathrm{g}$ plasmid DNA and was diluted to a final volume of $1 \mathrm{~mL}$ in $5 \%$ glucose solution.

\section{Gel retardation assays}

Electrophoresis was employed to confirm the DNA binding ability of the man-PEI-TEG derivates. The PEI/DNA complexes were prepared at PEI:DNA mass ratios of 2:1 and $3: 1$, then mixed with $6 \times$ loading buffer (Generay Biotech, Shanghai, China) and analyzed by gel electrophoresis on a $1.0 \%$ agarose gel containing $0.006 \%$ Goldview nucleic acid stain (Viswagen Biotech Pvt. Ltd, Kerala, India). After electrophoresis at $80 \mathrm{~V}$ for 45 minutes, the bands of plasmid DNA were visualized and photographed by molecular imager (ChemiDoc ${ }^{\mathrm{TM}}$ XRS system; Bio-Rad, Hercules, CA).

\section{DNase I protection assay}

The ability of man-PEI-TEG derivates to protect and release DNA in complex was ascertained by gel electrophoresis. ${ }^{26}$ In short, $2 \mu \mathrm{L}$ DNase I (1 unit) or phosphate-buffered saline
(PBS; as a negative control) were added to $10 \mu \mathrm{L}$ naked plasmid DNA solution $(0.5 \mu \mathrm{g})$ or DNA/PEI complex solutions (with the mass ratio of PEI:DNA 3:1), and this was shaken at $100 \mathrm{rpm}$ at $37^{\circ} \mathrm{C}$ for 1 hour. Following this, all of the samples were treated with $4 \mu \mathrm{L}$ EDTA $(250 \mathrm{mM})$ for 10 minute and then mixed with $10 \mu \mathrm{L}$ sodium dodecyl sulfate (SDS) (1\% in $0.1 \mathrm{M} \mathrm{NaOH}$ ) for the purpose of DNase I inactivation and DNA release, respectively. The samples were incubated at room temperature for 1 hour, and then electrophoresis was performed under the same conditions described above.

\section{Cytotoxicity assay}

The cytotoxicity of man-PEI-TEG derivates was evaluated by 3-(4,5-dimethylthiazol-2-yl)-2, 5-diphenyltetrazolium bromide (MTT) assay according to the method of Mosmann et al. ${ }^{27}$ The PEI/DNA complexes of each PEI derivate that was prepared at N/P ratios ranging from 5 to 50 were added to DC2.4 cells in 96-well plates. After incubation for 24 hours, MTT $(5 \mathrm{mg} / \mathrm{mL}, 20 \mu \mathrm{L})$ was added and reacted for 4 hours at $37^{\circ} \mathrm{C}$. Following this, the medium of each well was replaced with $150 \mu \mathrm{L}$ dimethylsulfoxide (DMSO) to dissolve the formazan crystals. The absorbance at $570 \mathrm{~nm}$ of each well was measured using a Varioskan ${ }^{\circledR}$ Flash multimode reader (Thermo Fisher Scientific, Waltham, MA). Cell viability was calculated by absorbance of cells pulsed with PEI, and absorbance of untreated cells $\times 100 \%$. All values presented below represent means of multiple measurements with SD values indicated.

\section{In vitro uptakes by DC2.4}

Twenty-four hours prior to the experiments, DC2.4 cells were seeded in 6-wells plates in which each well had been covered by sterile coverslips at $4 \times 105$ cells/well. The fluorescence-labeled complexes were prepared by mixing fluorescein isothiocyanate (FITC)-labeled PEI derivates with DNA plasmid at the optimal N/P ratio of each derivate. After vortexing and incubating the complex solutions at room temperature for 20 minutes, these were added to the DC2.4 cells adhered to the coverslips in the 6-well plates. Cells were then incubated for 1 hour at $37^{\circ} \mathrm{C}$; control cells were processed similarly but incubated at $4^{\circ} \mathrm{C}$. Coverslips were then washed by dipping in PBS prior to fixation with $4 \%$ paraformaldehyde ( 5 minutes, RT) and subsequent staining with $2 \mu \mathrm{g} / \mathrm{mL}$ diamidino phenylindole (DAPI). After washing the coverslips three times with PBS, they were then mounted on glass slides with $50 \%$ glycerol in $0.2 \mathrm{M}$ Tris- $\mathrm{HCl}(\mathrm{pH} 8.0$ ) containing 2\% n-propyl gallate to retard 
quenching of the fluorescence signal. Confocal microscopy was performed using a LSM510 confocal microscopy system (Carl Zeiss SMT GmBH, Heidelberg, Germany). All images were collected using the same values for photomultiplier gain, aperture diaphragm, and black levels.

\section{In vitro competition assay}

For competition assays, cells and fluorescence-labeled complexes were prepared as described above. To block the binding of man-PEI-TEG to MR, cells were pre-incubated for 20 minutes with $0.125 \mathrm{mg} / \mathrm{mL}$ mannan dissolved in RPMI-1640 or, as a control, with free RPMI-1640. Following this, FITC labeled complexes were added and cells were incubated for 1 hour at $37^{\circ} \mathrm{C}$. After washing the cells three times with PBS, these were removed from wells using $0.25 \%$ trypsin and resuspended in FACS buffer. The level of FITC fluorescence of cells was analyzed by flow cytometry using a FC500 flow cytometer (Beckman Coulter Inc, Brea, CA). Data analysis was performed using the Kaluza ${ }^{\circledR}$ software (Beckman Coulter Inc).

\section{In vitro DC2.4 transfection assay}

The transfection assay was performed on the DC2.4 cell line with the pGL4.10 (luc2) plasmid encoding luciferase as the reporter gene. DC2.4 cells cultured in RPMI-1640 and supplemented with $10 \%$ FBS were seeded onto 24-well plates at $1 \times 105$ cells/well 24 hours before transfection. When approximately $70 \%$ confluence was reached, the cells were gently washed twice with PBS and the medium of each well was replaced with $200 \mu \mathrm{L}$ serum-free culture medium. Following this, $25 \mu \mathrm{L}$ DNA/PEI complex solutions containing $1 \mu \mathrm{g}$ plasmid DNA at different N/P ratios was added to each well. After 4 hours of incubation, the transfection medium was removed and $1 \mathrm{~mL}$ fresh complete culture medium was added to each well and left to continue culturing for a further 20 hours at $37^{\circ} \mathrm{C}$ in a $5 \% \mathrm{CO}_{2}$ incubator. Luciferase expression was measured using a luciferase assay system (Promega Corporation, Madison, WI) following the manufacturer's instructions. The total protein concentration of transfected cells was determined by a BCA protein assay (KeyGEN, Nanjing, China). The luciferase expression level was calculated as relative lights units (RLU)/mg total protein.

\section{In vitro BMDCs maturation assay BMDCs culture}

Murine bone marrow-derived DCs (BMDCs) used in this experiment were derived as described by Inaba et al..$^{28}$ The bone marrow progenitor cells were harvested from 6-week-old C57BL/6 male mice that were purchased from West China Experimental Animal Center of Sichuan University (China). Ten mice were sacrificed and sterilized with $75 \%$ ethanol. Femurs were gently removed from mice and the muscles adhered on bones were removed with sterilized gauze. The bones were then immersed in $75 \%$ ethanol for 2 minutes for sterilization, then washed twice with ice-cold PBS (pH 7.2), and cultured in a petri dish containing ice-cold RPMI1640 medium. Both ends (epiphyses) of each bone were cut off and each hollow of the bones was flushed with $2 \mathrm{~mL}$ RPMI-1640 medium by inserting a needle into the hollow to obtain as many cells as possible. The cell suspension was filtered through a $70 \mu \mathrm{m}$ cell strainer (BD, Franklin Lakes, NJ) to remove tissue before centrifugation at $1000 \mathrm{rpm}$ for $10 \mathrm{~min}$ utes to collect cells. These were then washed with RPMI-1640 containing 10\% FBS (1640-10F) and cultured in petri dishes with R5 medium (RPMI-1640 medium supplemented with 20 ng/mL GM-CSF (R\&D Systems, Minneapolis, MN), $10 \mathrm{mM}$ HEPES, $50 \mu \mathrm{M}$ 2-mercaptoethanol, 10\% FBS, and antibiotic) at a total volume of $10 \mathrm{~mL}$ medium per dish. Cells were then washed and fed every 2 days. On day 4, aggregates of growing DC were observed attaching to the adherent stroma. These aggregates raised above the monolayer, in contrast to the flattened dispersed macrophage colonies. Spiky processes (dendrites) were also seen extending from the periphery of the aggregates, giving them a hairy or thistle-like appearance. On day 6 , the aggregates were harvested by gently pipetting over the adherent stroma. The cells were pooled and centrifuged before being resuspended with RPMI-1640 containing $50 \% \mathrm{FBS}(1640-50 \mathrm{~F})$, and incubated at $37^{\circ} \mathrm{C}$ for 30 minutes to dissociate the residual granulocytes. Following this, the cells were washed twice with 1640-10F medium and resuspended with R5 medium. They were then seeded into 6 -well plate at a cell density of $5 \times 106$ cells/well and a total volume of $2 \mathrm{~mL} /$ well.

To determine the purity of BMDCs (the percentage of $\mathrm{CD} 11 \mathrm{c}+$ cells), the FITC-labeled mouse CD11c antibody (eBiosience, San Diego, CA) was used to stain cells, which were then analyzed by flow cytometry. The percentage of CD11c+ cells in cultures was approximately $80 \%-90 \%$.

\section{BMDCs maturation in vitro}

The DNA/PEI complexes were prepared with their optimal $\mathrm{N} / \mathrm{P}$ ratios determined in the in vitro transfection experiment, and were added to BMDCs 6-well plates at $4 \mu \mathrm{g}$ DNA per well. PBS and $2 \mu \mathrm{g} / \mathrm{mL}$ lipopolysaccharide (LPS) were also added as the negative and positive control, respectively. After 
24 hours' incubation, cells were washed and stained with PE-Cy5/FITC/PE-labeled mouse CD80/CD86/CD40 antibody (eBiosience) at $4^{\circ} \mathrm{C}$ for 1 hour, then cells were determined by flow cytometry. The isotype control antibodies (eBiosience) for each type of the specific monoclonal antibody were employed to eliminate the autofluorescence of samples.

\section{Results}

\section{Synthesis and characterization of man-PEI-TEG}

The low molecular weight PEI polymers (PEI-TEG) and mannosylated PEI-TEG (man-PEI-TEG) were synthesized successfully. Figure 1 shows a simplified flowchart illus- trating the method of synthesis. The composition of the synthesized copolymers was analyzed by $1 \mathrm{H}-\mathrm{NMR}$, and the chemical shift of each proton peak is showed in Figure 2. The proton peak of the phenylisothiocyanate in mannopyranosylphenyl isothiocyanate $(-\mathrm{CH}-)$ appeared at 7.4-7.0 ppm, and the proton peaks of PEI (-NHCH2CH2-) appeared at 3.3-2.5 ppm, confirming that mannose had successfully been linked to PEI-TEG.

Gel permeation chromatography (GPC) analysis determined that the average molecular weights $(\mathrm{Mw})$ of PEI-TEG and three mannosylated derivates (A, B, and C) were $26.02,40.05,38.73$, and $34.40 \mathrm{kDa}$, respectively. The weight ratios of mannose residues in man-PEI-TEG (A, B,

A

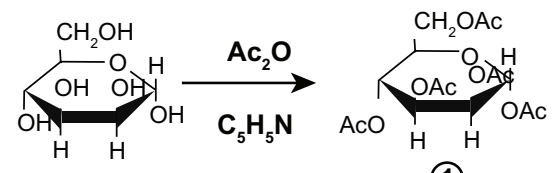

(1)

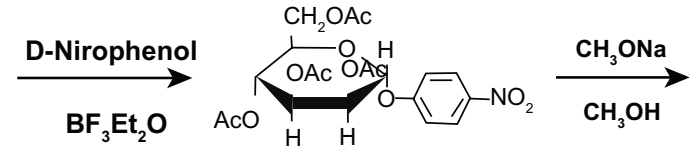

(2)

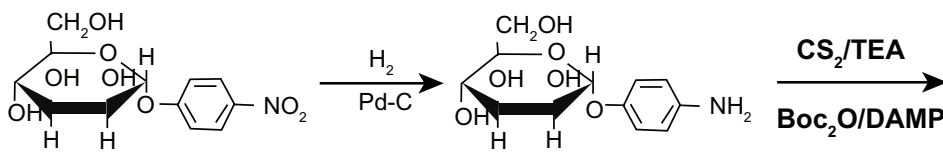

(3)

(4)

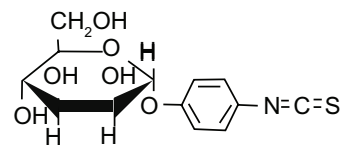

(5)

\section{B}

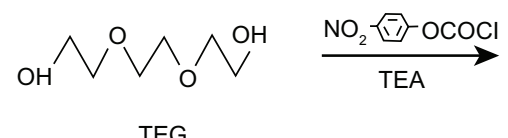

TEG<smiles>O=C(OCCOCCOC(=O)Oc1ccc([N+](=O)[O-])cc1)OCCOC(=O)Oc1ccc([N+](=O)[O-])cc1</smiles>

TEG-bis-NPC

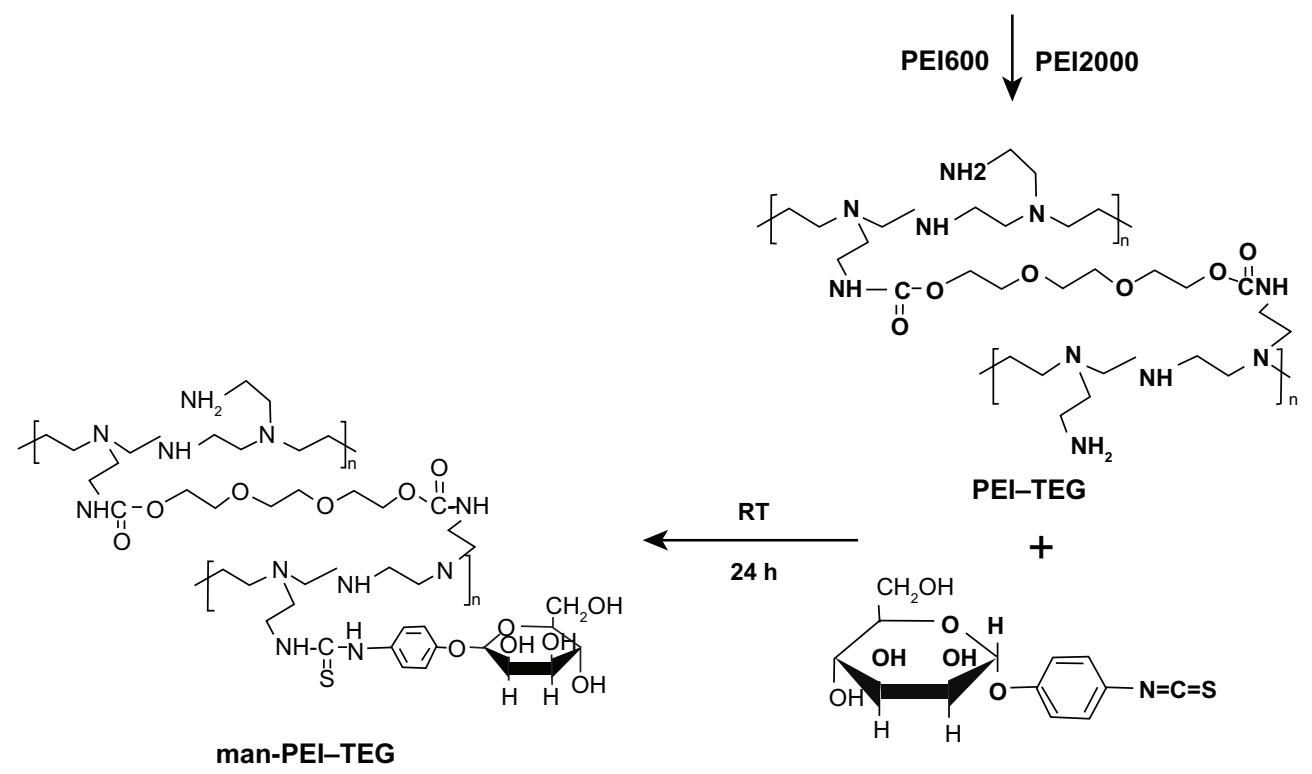

Mannopyranosylphenyl isothiocyanate

Figure I Synthetic route of mannosylated biodegradable PEI derivates. (A) mannopyranosylphenyl isothiocyanate; (B) PEI-TEG and man-PEI-TEG.

Abbreviations: Ac2O, acetic anhydride; $\mathrm{C} 5 \mathrm{H} 5 \mathrm{~N}$, pyridine; $\mathrm{BF} 3 \mathrm{Et} 2 \mathrm{O}$, boron fluoride ethyl ether; Pd-C, palladium-carbon; TEA, triethylamine; Boc2O, di-tert-butyl dicarbonate; PEI, polyethyleneimine; TEG, triethyleneglycol; PEI-TEG, polyethyleneimine and triethyleneglycol polymer; man-PEI-TEG, mannosylated PEI-TEG; NPC, 4-nitrophenyl chloroformate; PEI600, polyethyleneimine with a molecular weight of $0.6 \mathrm{kD}$; PEI2000, polyethyleneimine with a molecular weight of $2 \mathrm{kD}$; RT, room temperature. 


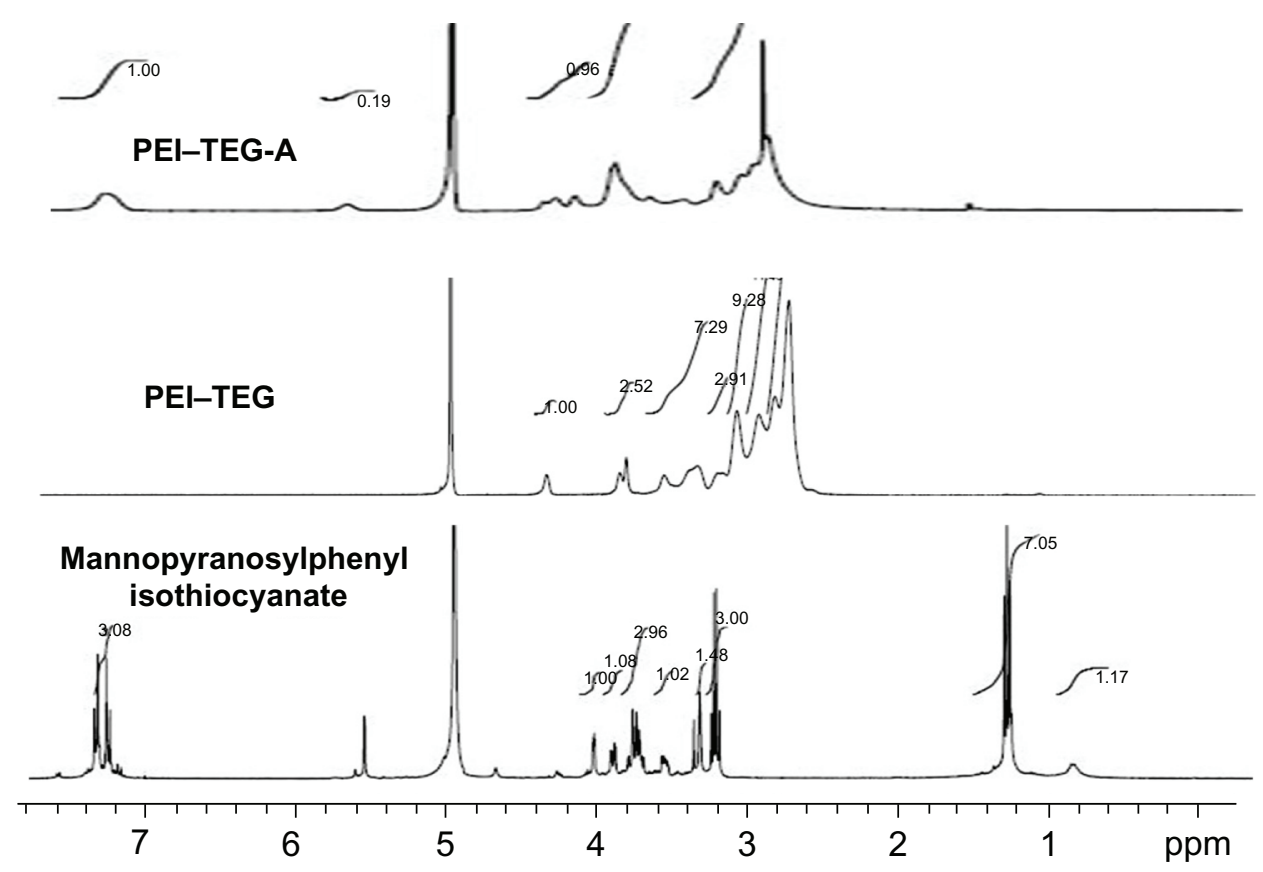

Figure 2 IH-NMR spectrum of mannopyranosylphenyl isothiocyanate in CD3OD: $\delta=7.1-7.2(4 \mathrm{Ar}-\mathrm{H}), \delta=5.5(\mathrm{Cl}-\mathrm{H}), \delta=3.2-4.0(\mathrm{C} 2-\mathrm{H}, \mathrm{C} 3-\mathrm{H}, \mathrm{C} 4-\mathrm{H}, \mathrm{C} 5-\mathrm{H} .2 \mathrm{C} 6-\mathrm{H})$; IH-NMR spectrum of PEI-TEG in D2O: $\delta=4.23(\mathrm{NHCOOCH} 2 \mathrm{CH} 2 \mathrm{OCH} 2), \delta=3.77(\mathrm{NHCOOCH} 2 \mathrm{CH} 2 \mathrm{OCH} 2), \delta=3.73(\mathrm{NHCOOCH} 2 \mathrm{CH} 2 \mathrm{OCH} 2), \delta=3.48$; IH-NMR spectrum of PEI-TEG-A in D2O: $\delta=4.23\left(\mathrm{NHCOOCH}_{2} \mathrm{CH} 2 \mathrm{OCH} 2\right), \delta=3.77\left(\mathrm{NHCOOCH}_{2} \mathrm{CH}_{2} \mathrm{OCH} 2\right), \delta=3.73(\mathrm{NHCOOCH} 2 \mathrm{CH} 2 \mathrm{OCH} 2), \delta=3.48$ $\left(\mathrm{HOCH}_{2} \mathrm{CH}_{2} \mathrm{OCH} 2\right), \delta=3.3-2.5\left(-\mathrm{NHCH}_{2} \mathrm{CH} 2-\right), \delta=7.0-7.4(-\mathrm{CH}-$, mannopyranosylphenyl isothiocyanate).

Abbreviations: PEI, polyethyleneimine; TEG, triethyleneglycol; PEI-TEG, polyethyleneimine and triethyleneglycol polymer; PEI-TEG-A, mannosylated PEI-TEG derivative A; Ppm, parts per million.

and C) were calculated to be $35.0 \%, 32.8 \%$, and $24.4 \%$, respectively, which were consistent with the theoretical values (Table 1).

\section{Characterization of PEI/DNA complex}

A series of PEI/DNA complexes were successful obtained, and their $\mathrm{pH}$ ranged from 4.3 to 5.2 in $5 \%$ glucose solution. The DNA conveyance ability of PEI-TEG and man-PEITEG was evaluated by examining properties such as zeta potential, particle size, and their ability to bind and protect DNA from DNase degradation.

The results of the average size and zeta-potential assays are shown in Figure 3, and it can be seen that the average particle size of all the complex samples spanned a range from 110 to $260 \mathrm{~nm}$, with a narrow size distribution (PDI $<0.2)$. Moreover, all of the DNA/PEI complexes (except those of derivates A and $B$ at the N/P ratio of 5) were positively charged, with the positive charge increasing as the N/P ratio increased from 5 to 40 .

The binding and condensation capability of the PEI derivates with DNA plasmid was evaluated using agarose gel electrophoresis. As shown in Figure 4A, when the mass ratio of PEI:DNA was 2:1, PEI25k, PEI-TEG, and manPEI-TEG-C could retard DNA completely, while man-PEITEG-A and man-PEI-TEG-B could not retard all of the DNA plasmid. However, when the mass ratio increased to 3:1, no
DNA band was seen, which indicates that all of the samples can retard DNA.

Figure 4B shows the result of DNase I protection. After being treated with DNase I for 1 hour at $37^{\circ} \mathrm{C}$, mannosylated derivates A, B, and C, as well as PEI 25k and PEI-TEG, were able to protect DNA from enzymatic degradation at the mass ratio of 3:1. This is in contrast to naked plasmid DNA.

\section{In vitro cytotoxicity, cellular uptake, and transfection on DC2.4}

DC2.4, a dendritic cell line that expresses moderate MRs, ${ }^{10,29}$ was used to determine the cytotoxicity, cellular uptake, and transfection efficiency of the PEI derivates/DNA complexes in vitro.

As is shown in Figure 5, cytotoxicity increased for all PEI/ DNA complexes as the N/P ratio increased, and the viability of cells treated by the three mannosylated derivates (A, B, and $\mathrm{C}$ ) as well as PEI-TEG was significantly higher than that of commercial PEI25k. As well as this, when the N/P ratio was greater than 30 the relative cell viabilities of PEI-TEG began to decrease quickly, while those of the mannosylated derivates $(\mathrm{A}, \mathrm{B}$, and $\mathrm{C}$ ) remained above $80 \%$ even at the highest N/P ratio of 50.

The expression of reporter genes was evaluated using a luciferase assay system, and the data shown 

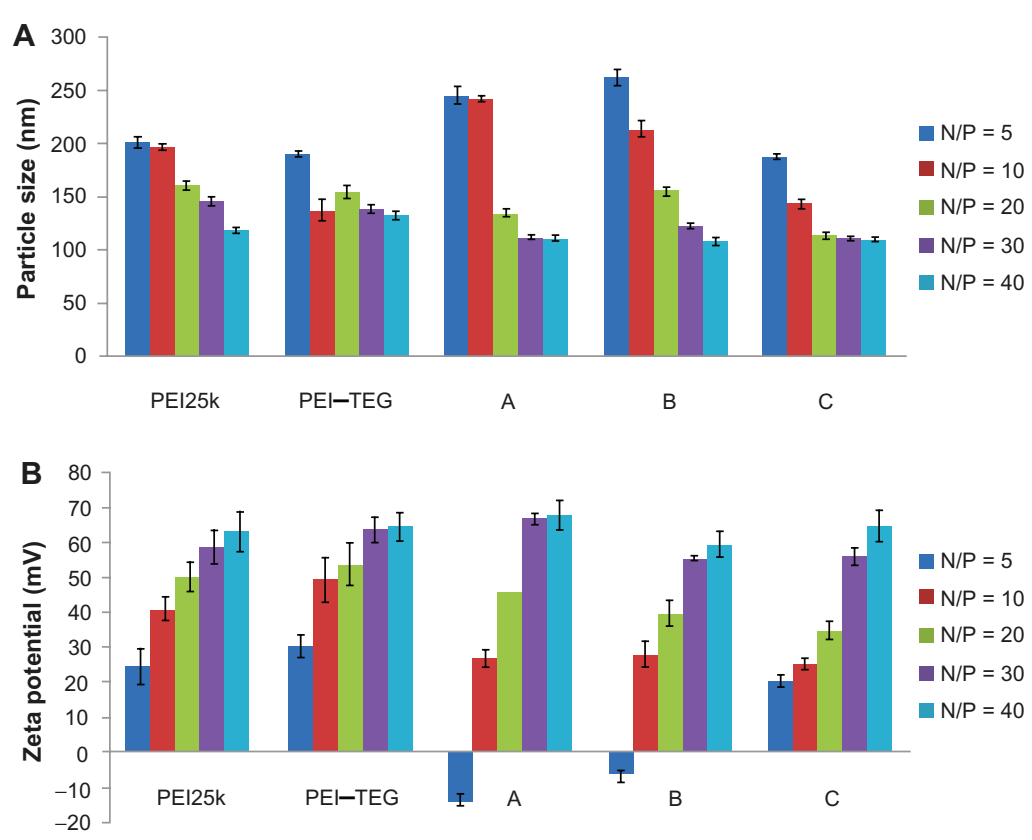

Figure 3 Characterization of PEI/DNA complex $(n=3)$. (A) Average particle size, $(\mathbf{B})$ Zeta-potential.

Note: The PEI/DNA complexes were prepared at an N/P ratio ranging from 5:I to 40:I, determined using photon correlation spectroscopy.

Abbreviations: PEI, polyethyleneimine; TEG, triethyleneglycol; PEI-TEG, polyethyleneimine and triethyleneglycol polymer; A, mannosylated PEI-TEG derivative A; B, mannosylated PEI-TEG derivative B; C, mannosylated PEI-TEG derivative C; PEI25k, polyethyleneimine with a molecular weight of 25 kD.

in Figure 6 indicate that the luciferase expression in cells transfected with the positive control PEI25k/DNA complex was about 100 times greater than the expression of the naked plasmid DNA-treated group $(P<0.01)$, but remained 2-3 times lower than that of the PEI-TEG/DNA complex $(P<0.03)$. In contrast to this, the man-PEI-TEG/ DNA complexes exhibited an approximately three-times higher transfection efficiency than the complexes made from the PEI-TEG $(P<0.01)$. Among the three mannosylated PEI-TEG derivates, B (with the mannose weight

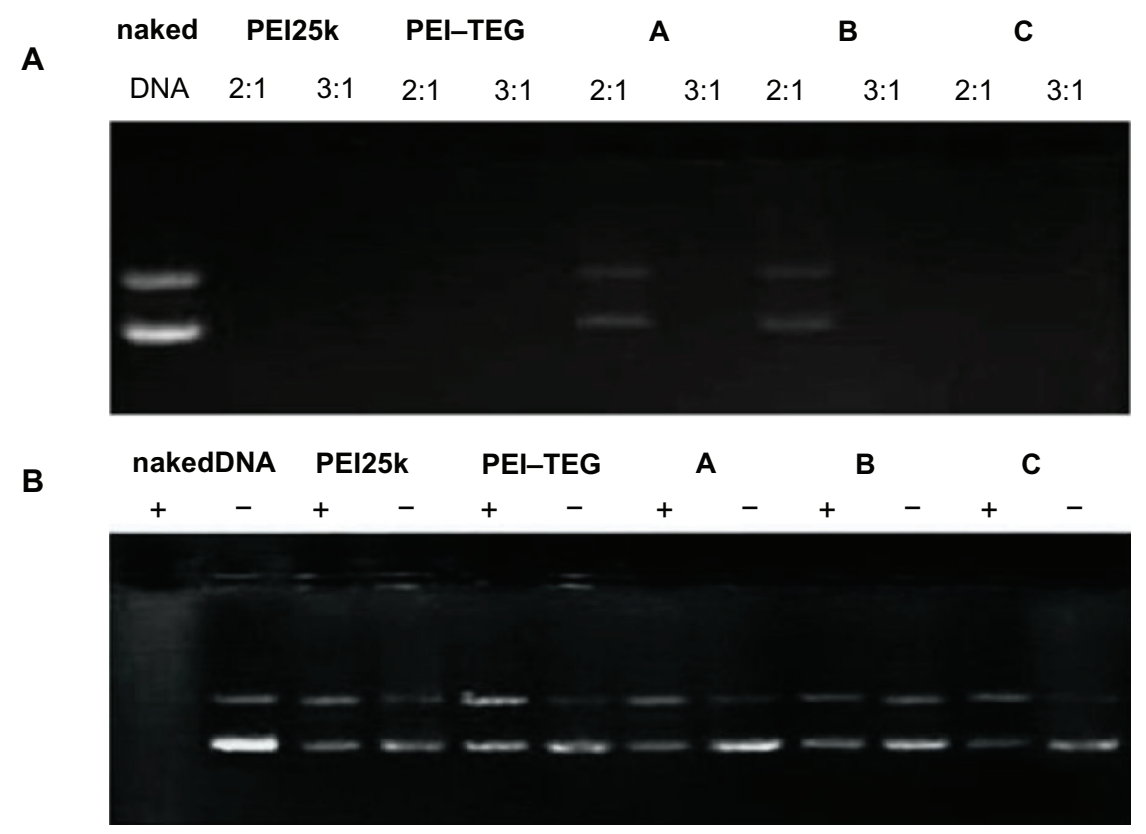

Figure 4 DNA retardation and DNase I protection assay. (A) DNA-binding abilities of all PEl derivates were examined by agarose gel electrophoresis, and the examining mass ratios of PEI:DNA were 2:I and 3:I respectively. (B) PEI/DNA complexes were prepared at a ratio of 3:I (w/w) and tested for their abilities to protecting DNA against the DNase I degradation.

Notes: +, samples treated with DNase I; -, samples treated with PBS.

Abbreviations: PEI, polyethyleneimine; TEG, triethyleneglycol; PEI-TEG, polyethyleneimine and triethyleneglycol polymer; A, mannosylated PEI-TEG derivative A; B, mannosylated PEI-TEG derivative B; C, mannosylated PEI-TEG derivative C; PEI25k, polyethyleneimine with a molecular weight of $25 \mathrm{kD}$. 


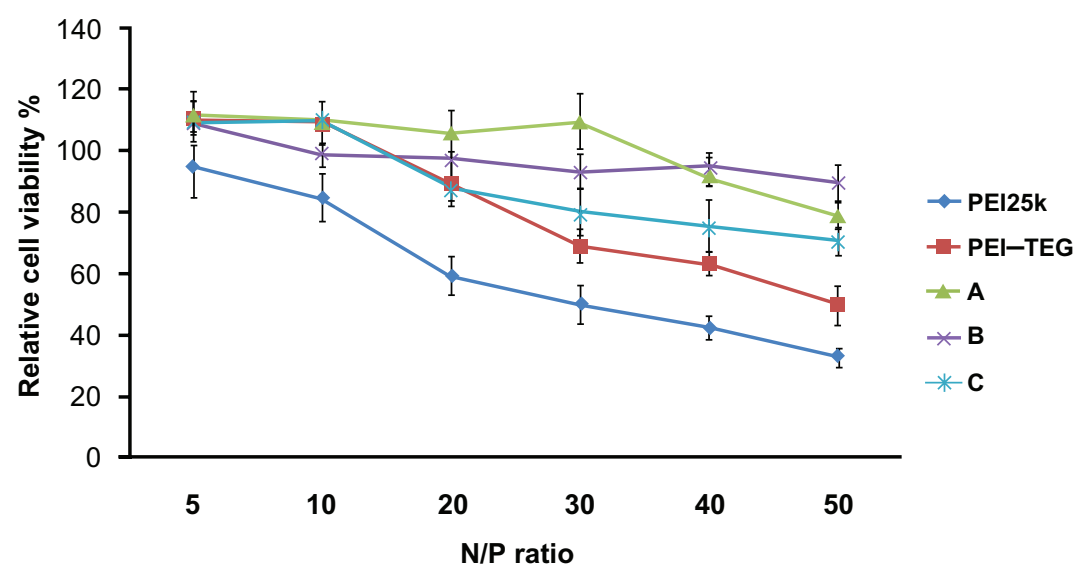

Figure 5 Cytotoxicity tests of the PEI/DNA complexes on the DC2.4 cell line.

Notes: The viability of cells treated with PEI/DNA complexes at various N/P ratios was measured by the MTT assay, and cells treated with culture media only were taken to be $100 \%$ viable. The data were represented as mean \pm standard deviation (SD) of three independent experiments $(n=3)$.

Abbreviations: PEI, polyethyleneimine; TEG, triethyleneglycol; PEI-TEG, polyethyleneimine and triethyleneglycol polymer; A, mannosylated PEI-TEG derivative A; B, mannosylated PEI-TEG derivative B; C, mannosylated PEI-TEG derivative C; PEI25k, polyethyleneimine with a molecular weight of 25 kD; DC, dendritic cells; MTT, 3-(4,5-dimethylthiazol-2-yl)-2, 5-diphenyltetrazolium bromide; SD, standard deviation.

ratio of $32.8 \%$ ) appeared to result in the highest transfection efficiency $(P<0.03)$.

The introduction of mannose as a ligand into the gene carriers for specific recognition by DC cells may enhance the transfer across the cell membrane, so the cellular uptake of complexes was also determined. Cells were incubated with FITC-labeled PEI derivates/DNA complexes at $37^{\circ} \mathrm{C} / 4^{\circ} \mathrm{C}$ for 1 hour and then photographed by confocal microscopy. As is shown in Figure 7, after being incubated at $37^{\circ} \mathrm{C}$ for 1 hour the cells treated with man-PEI-TEG-B exhibited significantly more green fluorescence than those treated with PEI25k and PEI-TEG. For man-PEI-TEG-B, almost all of the green fluorescence was observed within the cells. In contrast, for PEI25k and, to an even greater extent, PEI-TEG, a large proportion of the green fluorescence did not enter the cell but only adsorbed onto the surface of the cells, so most of the green fluorescence was observed in rings around the cells. The uptake results of the three groups at $4{ }^{\circ} \mathrm{C}$ were approximately the same, indicating that almost no complex was taken up by cells.

In order to further investigate the mechanism of internalization of mannosylated complexes, a competition experiment was performed with mannan. As is shown in Figure 8, the mean fluorescence intensity (MFI) of man-PEI-TEG cells pre-incubated with mannan was 4-5-fold lower than that of

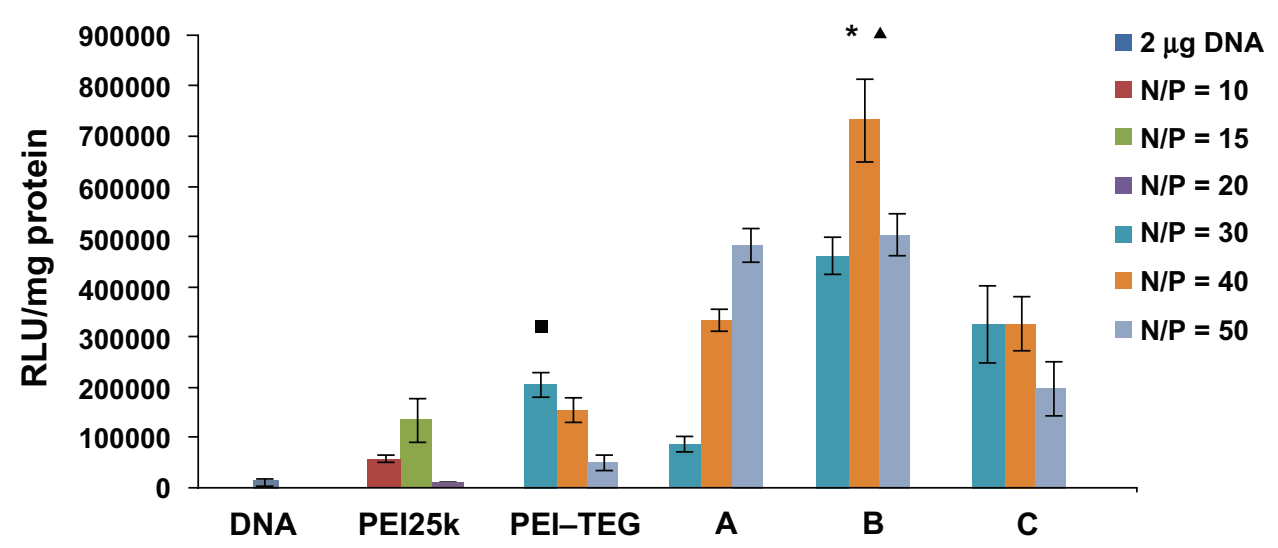

Figure 6 The transfection efficiency of PEI derivates/DNA complexes on the DC2.4 cell line in the absence of serum. The N/P ratios of complexes were optimized by a preliminary experiment, and the optimal N/P ratio of complex of PEI25k, PEI-TEG, and man-PEI-TEG conjugates A, B, and C were I0, 30, 50, 40, and 30, respectively. The data were represented as mean \pm standard deviation (SD) of three independent experiments $(n=3)$.

Notes: ${ }^{-} P<0.03$ vs the group of $P E I 25 k$ at its optimal N/P ratio; ${ }^{\star} P<0.00$ I vs the group of $P E I 25 k$ and $P E I-T E G$ at their optimal N/P ratio; ${ }^{\Delta} P<0.03$ vs the group of man-PEI-TEG conjugates $A$ and $C$ at their optimal N/P ratio.

Abbreviations: PEI, polyethyleneimine; TEG, triethyleneglycol; PEI-TEG, polyethyleneimine and triethyleneglycol polymer; A, mannosylated PEI-TEG derivative A; B, mannosylated PEI-TEG derivative B; C, mannosylated PEI-TEG derivative C; PEI25k, polyethyleneimine with a molecular weight of $25 \mathrm{kD}$; DC, dendritic cells; RLU, relative light unit; SD, standard deviation. 


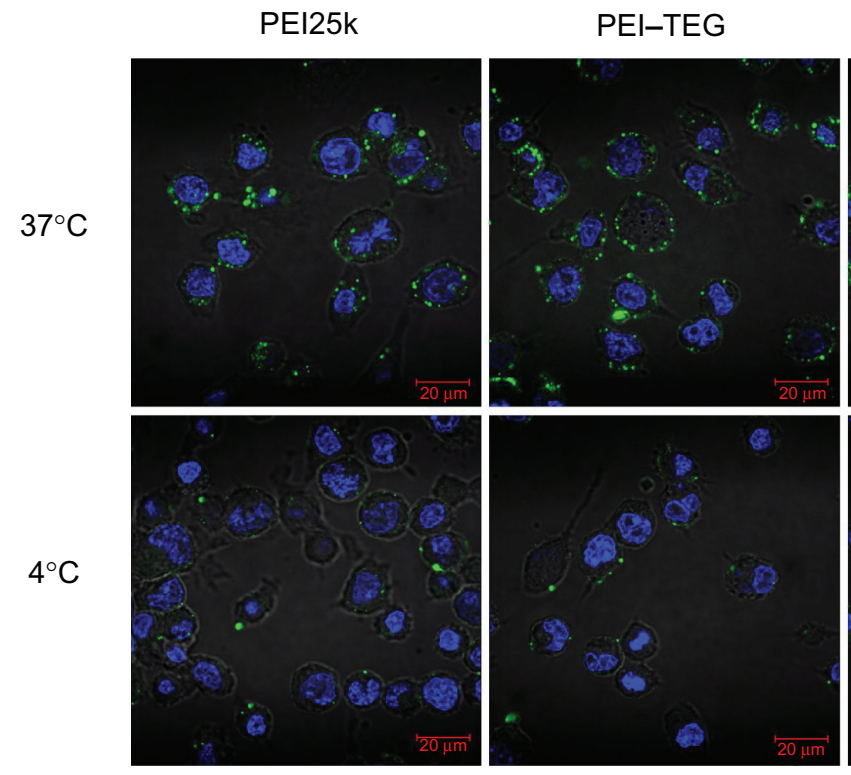

man-PEI-TEG-B
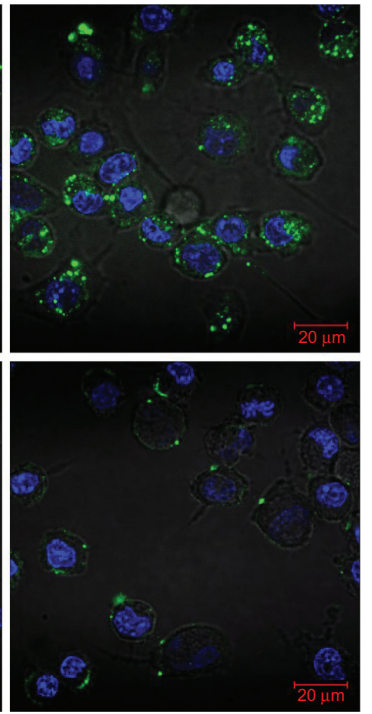

Figure 7 Confocal micrographs of cellular uptake of complexes on the DC2.4 cell line.

Notes: Cells were incubated with complexes prepared from PEI $25 \mathrm{k}$, PEI-TEG, and man-PEI-TEG-B, respectively, at $37^{\circ} \mathrm{C} / 4^{\circ} \mathrm{C}$ for I hour prior to fixation with $4 \%$ paraformaldehyde (5 minutes, RT) and staining with $2 \mu \mathrm{g} / \mathrm{mL}$ diamidino phenyl indole (DAPI). Green fluorescence, FITC; blue fluorescence, DAPI.

Abbreviations: PEI, polyethyleneimine; TEG, triethyleneglycol; PEI-TEG, polyethyleneimine and triethyleneglycol polymer; man-PEI-TEG-B, mannosylated PEI-TEG derivative B; PEI25k, polyethyleneimine with a molecular weight of 25 kD; DC, dendritic cells; RT, room temperature; DAPI, diamidino phenyl indole; FITC, fluorescein Isothiocyanate.

control cells. For PEI25k and PEI-TEG, the MFI of the two groups of cells were very similar.

\section{BMDCs maturation in vitro}

To assess the effect of PEI/DNA complexes on the maturation of mouse BMDCs, levels of the costimulatory molecules CD40, CD80, and CD86 were measured by flow cytometry. As is shown in Figure 9, after 24 hours of culturing with BMDCs, the positive control LPS conspicuously upregulated the expression of the three costimulatory molecules, while PEI25k, PEI-TEG, and man-PEI-TEG all induced remarkable upregulation of the molecules compared to the negative control $(P<0.01)$, but this was not as strong as that of LPS $(P<0.01)$, and the upregulation
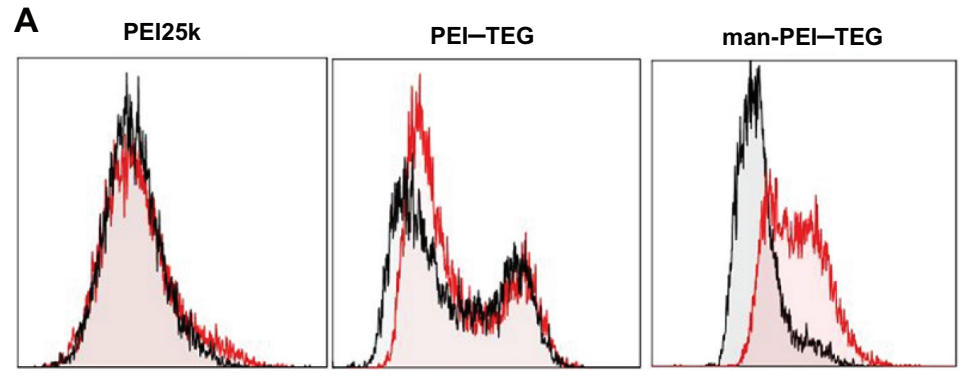

With mannose

Without mannose

\section{B}

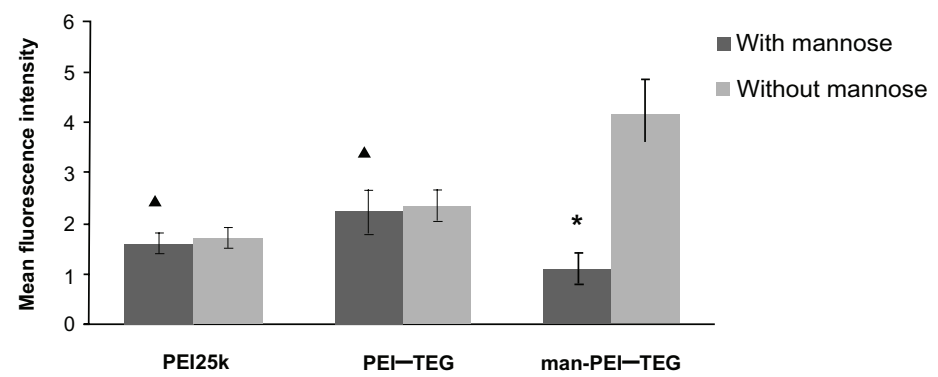

Figure 8 Competition assay with mannan. Prior to the incubation with FITC labeled complexes, cells were pre-incubated with $0.125 \mathrm{mg} / \mathrm{mg}$ mannan for 20 minutes or as control with free medium. (A) A representative set of flow cytometry histograms. (B) The mean fluorescence intensity (MFI) of each group of cells.

Notes: ${ }^{\star} P<0.01$, vs its control group; $\triangle P>0.05$, vs its control group.

Abbreviations: PEI, polyethyleneimine; TEG, triethyleneglycol; PEI-TEG, polyethyleneimine and triethyleneglycol polymer; man-PEI-TEG, mannosylated PEI-TEG; PEI25k, polyethyleneimine with a molecular weight of $25 \mathrm{kD}$. 
A
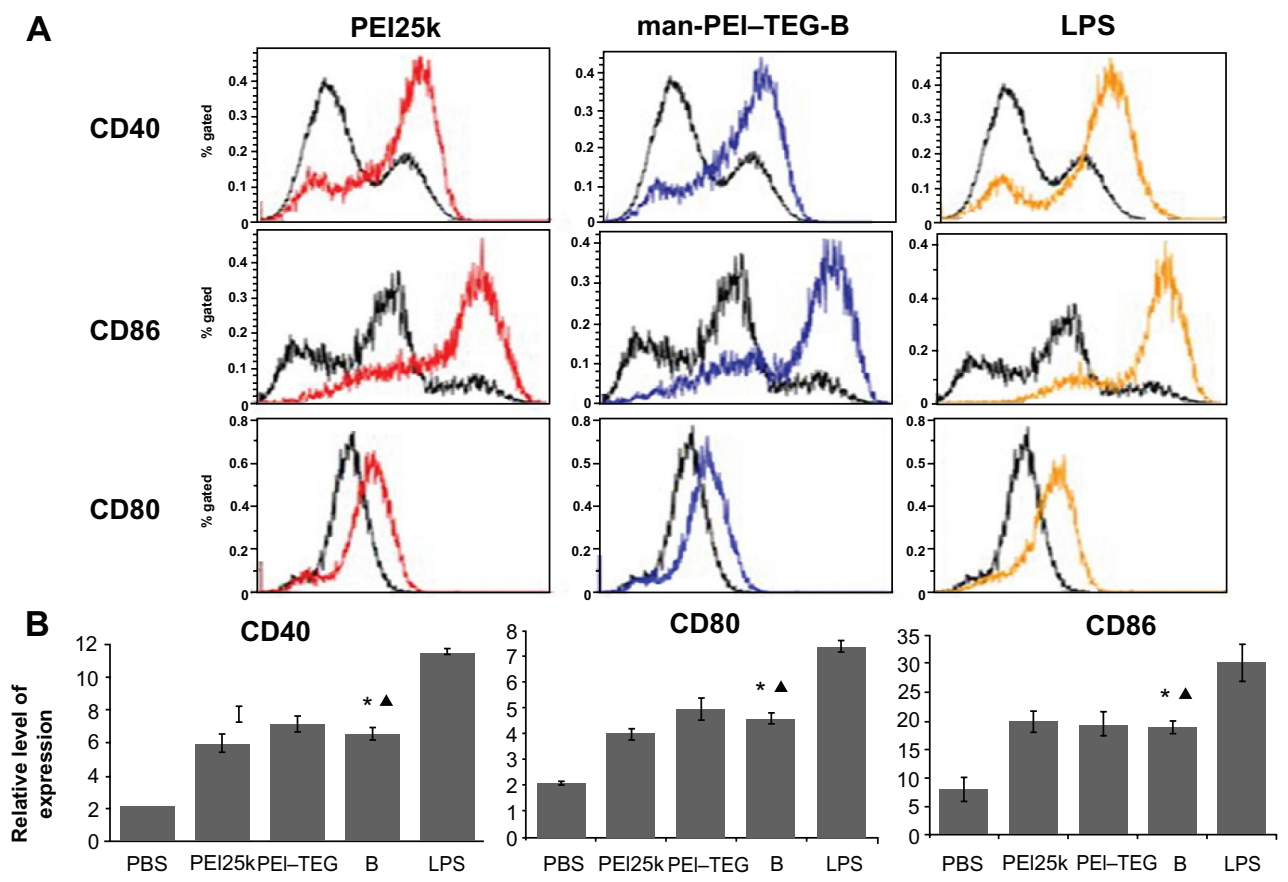

Figure 9 Expression of maturation surface markers (CD40, CD80, and CD86) in BMDCs treated with PEI/DNA complexes. PEI/DNA complexes were prepared at their optimal N/P ratio, and cells treated with PBS and LPS were used as the negative and positive controls, respectively. (A) A representative set of flow cytometry histograms. Black line: cells treated with PBS. (B) Normalized expression level of maturation markers. The data were represented as mean \pm standard deviation (SD) of three independent experiments $(n=3)$.

Notes: ${ }^{\star} P<0.01$, vs the group of PBS and LPS; $\triangle P>0.05$, vs the group of PEI25k and PEI-TEG.

Abbreviations: PEI, polyethyleneimine; TEG, triethyleneglycol; PEI-TEG, polyethyleneimine and triethyleneglycol polymer; man-PEI-TEG-B, mannosylated PEI-TEG derivative B; PEI25k, polyethyleneimine with a molecular weight of 25 kD; DC, dendritic cells; BMDC, Murine bone marrow-derived DCs; LPS, lipopolysaccharide; SD, standard deviation.

intensity of the three carriers were approximately the same $(P>0.05)$.

\section{Discussion}

In the present study, a series of mannosylated biodegradable LMW-PEI polymers (man-PEI-TEG) were designed and synthesized. The LMW-PEI polymer (PEI-TEG) was synthesized with triethyleneglycol (TEG) as the cross-linker and, to be assigned the DC specificity, the PEI-TEG was mannosylated by the thiourea reaction between the isothiocyanate group of mannopyranosylphenyl isothiocyanate and the primary amine groups of PEI-TEG. Three man-PEI-TEG conjugates $(\mathrm{A}, \mathrm{B}$, and $\mathrm{C})$ were obtained, for which the mannose substitution degrees were $35 \%, 32.8 \%$, and $24.4 \%$, respectively. It appears that this is the first time that this kind of PEI derivate has been reported.

To ensure that the PEI-TEG and its mannosylated derivates that were generated are capable of delivering plasmid DNA, they must be able to bind and condense the plasmid DNA as efficiently as PEI alone. The results of gel electrophoresis to ascertain derivates' DNA condensation ability suggest that the DNA binding abilities of PEI25k, PEI-TEG, and $\mathrm{C}$ were stronger than those of $\mathrm{A}$ and $\mathrm{B}$ (Figure 4), which may be ascribed to the less positive charge that A and B have due to the mannosylation of the primary amines. This suggests that a higher weight ratio of $\mathrm{A} / \mathrm{B}$ to DNA is required to completely condense plasmid DNA, while DNA in the gene vehicle should be protected from enzymatic degradation for efficient transfection. The electrophoresis assay also indicated that PEI-TEG and its mannosylated derivates A, B, and C were all able to protect DNA against hydrolysis by nucleases. Furthermore, according to the results of photon correlation spectroscopy, the particle sizes of all PEI/DNA complexes made by these derivates were nano-sized (110-260 nm) with a narrow distribution, which would be favorable for gene delivery. These results indicate that the man-PEI-TEG derivates have retained the excellent properties of PEI for a self-assembled nanoparticle system.

Applicable gene carriers should be non-toxic or minimally toxic, so it was necessary to measure the cytotoxicity of the PEI derivates using a MTT assay. The results (Figure 5) indicate that the cytotoxicity of complexes prepared by PEI-TEG was significantly lower than that of commercial PEI25k, which was consistent with previous studies. ${ }^{8}$ When the N/P ratio increased to 30 , however, the cytotoxicity of the PEI-TEG/DNA complexes increased, while those of the man- 
PEI-TEG/DNA complexes remained low. This indicates that the incorporation of mannose residues played a further role in diminishing the toxicity of carriers.

In the preliminary transfection experiment it was initially found that the transfection efficiency of PEI derivates would be enhanced as the N/P ratio of the PEI/DNA complex was increased. When the N/P ratio was increased too much, however, the transfection efficiency began to drop due to the increasing cytotoxicity of the complexes. As the cytotoxicity of the carriers differed, the optimal transfection N/P ratio for each polymer was selected to ensure that all carriers could obtain an optimal transfection efficiency (data not shown). In the DC2.4 cell line, the optimal N/P ratios of the complex of PEI25k, PEI-TEG, and man-PEI-TEG conjugates A, B, and $C$ were $10,30,50,40$, and 30 , respectively. Based on the MTT assay, the relative cell viabilities of complexes were all above $80 \%$ at their optimal N/P ratio. It was demonstrated in the transfection result (Figure 6) that the biodegradable LMW-PEI polymer PEI-TEG had a better performance in transfection than commercial PEI25k. The most likely reason for this is that the degradable PEI-TEG polymer had a capacity for binding to negatively charged molecules (such as translation-related proteins or mRNA) in the cytoplasm, which would inhibit transfection. ${ }^{8,30}$ Moreover, the mannose residues significantly improved the transfection efficiency of the carrier system. The degree of mannosylation, however, did not simply increase as more mannose was added. In a previous study mannosylated derivates were introduced with different PEI-TEG to mannopyranosylphenyl isothiocyanate feed ratios $(1: 4,1: 3,1: 2,4: 1$, and $8: 1)$, and these had an inferior performance to those in the current study $(1: 1$, $2: 1$, and $3: 1$ ) (data not shown). Moreover, among the three mannosylated derivates reported here, $\mathrm{B}$ (32.8\% mannose) performed better than A (35\% mannose) and C (24.4\% mannose). As has been reported previously, ${ }^{3,5}$ the cationic polymer PEI has a strong buffering capacity due to the numerous primary amines in its structure, and this could protect DNA from nuclease degradation and facilitate endosomal escape through the "proton sponge hypothesis," so becoming highly efficient at delivering DNA. In order to synthesize the man-PEI-TEG conjugate, mannose had to be linked to PEI via a phenylisothiocyanate bridge between the isothiocyanate group of mannopyranosylphenyl isothiocyanate and the primary amine groups of PEI, which meant that the more mannose residues that were linked the weaker buffering capacity the conjugates had. The result of this was that while the mannose residues could offer the carry system the potential to target the MRs expressed on DCs and thus enhance their uptake by receptor-mediated endocytosis, after uptake by cells these residues could slow the further function of PEI. This indicates that it is important to find a balance between those two factors; the current study suggests that man-PEI-TEG-B has optimal mannosylation.

The improved cellular trafficking of synthesized polymers was also confirmed by confocal microscopy. As shown in Figure 7, significantly more fluorescence had been internalized by cells treated with man-PEITEG-B and localized in cytoplasm after 60 minutes' incubation at $37^{\circ} \mathrm{C}$ than was observed in either PEI25k or PEI-TEG. Additionally, the complexes prepared with PEI-TEG were more likely to be located at the area close to the membrane, while most of the green fluorescence appeared within the cells of the man-PEI-TEG-B-treated group. This indicates that, as expected, incorporation of mannose ligand can facilitate the cellular uptake of the complexes via an alternative pathway that was most likely receptor-mediated endocytosis. However, the correlation between the amount of uptake and the substitution degrees of mannose ligand was not significant in the current study (data not shown).

Furthermore, as was observed in the competition assay (Figure 8), the uptake of man-PEI-TEG/DNA complexes was significantly inhibited in the presence of mannan, while those of PEI25k/DNA and PEI-TEG/DNA were relatively unaffected. This confirmed our hypothesis that the internalization of the mannosylated complexes predominantly occurs via mechanisms dependent on MRs on the cell surface (that is, MR-mediated endocytosis).

It is well known that immature DCs (iDCs) are specialized for antigen capture whereas mature DCs are capable of antigen-presentation and T cell-priming, and the ability of DCs to regulate immunity is dependent on DC maturation stage. This means that when a gene-delivery system targeting DCs is designed, the DC maturation ability of the system is a crucial parameter to consider. A variety of factors can induce maturation following antigen uptake and processing within DCs, including whole bacteria or bacterial-derived antigens (eg, lipopolysaccharide), ligands of certain cell surface receptors (eg, CD40), inflammatory cytokines, and viral products (eg, doublestranded RNA). During their conversion from immature to mature cells, DCs undergo a number of phenotypical and functional changes including a redistribution of major histocompatibility complex molecules from intracellular endocytic compartments to the DC surface, down-regulation of antigen internalization, and upregulation of the surface 
expression of costimulatory molecules such as CD40, CD80, and CD86. ${ }^{31-35}$ With this in mind, the maturation stage of BMDCs through the expressing level of CD40, CD80, and CD86 were examined with PBS and LPS as negative and positive controls, respectively. The results, shown in Figure 9, show that the maturation abilities of complexes based on PEI derivates were not as strong as those of LPS. However, compared to other systems such as poly(lactic-co-glycolic acid) and polyethylene glycol-blockpoly(aminoethyl methacrylate), ${ }^{36,37}$ which had been reported to only slightly alter the phenotypes of iBMDCs, the PEI system in the current study could significantly upregulate the expression of the costimulatory molecules. Given that CD40 and CD86 play an important role in the induction of adaptive immunity through activation of CD4+ T cells, this result would be beneficial for the application of DNA vaccines specifically targeting DCs. ${ }^{33}$

\section{Conclusion}

In this study, a series of man-PEI-TEGs were successfully synthesized and evaluated as a novel gene delivery carrier for DC targeting. The man-PEI-TEG polymers demonstrated the ability to form PEI/DNA complexes with physicochemical properties that would make them suitable as a gene delivery carrier. Furthermore, man-PEI-TEG showed significantly lower cytotoxicity and higher transfection efficiency on the DC2.4 cell line than commercial PEI25k, and demonstrated adequate maturation ability on BMDCs. With further improvement, it appears that these mannosylated PEI polymers will show potential as carriers for targeting DNA vaccines to DCs.

\section{Acknowledgments}

We are thankful for the financial support of the National Natural Science Foundation of China (No 30973657), Program for New Century Excellent Talents in University (No TEC-10-0601), and the National Science and Technology Major Project of China (No 2011ZX09401-304(4-3)).

\section{Disclosure}

The authors report no conflicts of interest in this work.

\section{References}

1. Liu MA. DNA vaccines: a review. J Intern Med. 2003;253(4): 402-410.

2. Mintzer MA, Simanek EE. Nonviral vectors for gene delivery. Chem Rev. 2009;109(2):259-302.

3. Boussif O, Lezoualc'h F, Zanta MA, et al. A versatile vector for gene and oligonucleotide transfer into cells in culture and in vivo: polyethylenimine. Proc Natl Acad Sci U S A. 1995;92(16):7297-7301.
4. Fischer D, LiY, Ahlemeyer B, Krieglstein J, Kissel T. In vitro cytotoxicity testing of polycations: influence of polymer structure on cell viability and hemolysis. Biomaterials. 2003;24(7):1121-1131.

5. Godbey WT, Wu KK, Mikos AG. Poly(ethylenimine) and its role in gene delivery. J Control Release. 1999;60(2-3):149-160.

6. Fischer D, Bieberf T, Li Y, Elsässer HP, Kissel T. A novel non-viral vector for DNA delivery based on low molecular weight, branched polyethylenimine: effect of molecular weight on transfection efficiency and cytotoxicity. Pharm Res. 1999;16(8):1273-1279.

7. Tang GP, Yang Z, Zhou J. Poly (ethylenimine)-grafted-poly [(aspartic acid)-co-lysine], a potential non-viral vector for DNA delivery. J Biomater Sci Polym Ed. 2006;17(4):461-480.

8. Zhao D, Gong T, Zhu D, Zhang Z, Sun X. Comprehensive comparison of two new biodegradable gene carriers. Int J Pharm. 2011;413(1-2): 260-270.

9. Mellman I, Steinman RM. Dendritic cells: specialized and regulated antigen processing machines. Cell. 2001;106(3):255-258.

10. Taylor ME, Conary JT, Lennartz MR, Stahl PD, Drickamer K. Primary structure of the mannose receptor contains multiple motifs resembling carbohydrate-recognition domains. J Biol Chem. 1990; 265(21):12156-12162.

11. Tan MC, Mommaas AM, Drijfhout JW, et al. Mannose receptormediated uptake of antigens strongly enhances HLA class II-restricted antigen presentation by cultured dendritic cells. Eur J Immunol. 1997; 27(9):2426-2435.

12. Apostolopoulos V, McKenzie IF. Role of the mannose receptor in the immune response. Curr Mol Med. 2001;1(4):469-474.

13. East L, Isacke CM. The mannose receptor family. Biochim Biophys Acta. 2002;1572(2-3):364-386.

14. Keler T, Ramakrishna V, Fanger MW. Mannose receptor-targeted vaccines. Expert Opin Biol Ther. 2004;4(12):1953-1962.

15. Jiang HL, Kang ML, Quan JS, et al. The potential of mannosylated chitosan microspheres to target macrophage mannose receptors in an adjuvant-delivery system for intranasal immunization. Biomaterials. 2008;29(12):1931-1939.

16. Perche F, Gosset D, Mevel M, et al. Selective gene delivery in dendritic cells with mannosylated and histidylated lipopolyplexes. J Drug Target. 2011;19(5):315-325.

17. Kim N, Jiang D, Jacobi AM, et al. Synthesis and characterization of mannosylated pegylated polyethylenimine as a carrier for siRNA. Int J Pharm. 2012;427(1):123-133.

18. Diebold SS, Kursa M, Wagner E, Cotten M, Zenke M. Mannose polyethylenimine conjugates for targeted DNA delivery into dendritic cells. J Biol Chem. 1999;274(27):19087-19094.

19. Park IY, Kim IY, Yoo MK, Choi YJ, Cho MH, Cho CS. Mannosylated polyethylenimine coupled mesoporous silica nanoparticles for receptormediated gene delivery. Int J Pharm. 2008;359(1-2):280-287.

20. Jiang HL, Kim YK, Arote R, et al. Mannosylated chitosan-graftpolyethylenimine as a gene carrier for Raw 264.7 cell targeting. Int $J$ Pharm. 2009;375(1-2):133-139.

21. Munch H, Hansen JS, Pittelkow M, Christensen JB, Boas U. A new efficient synthesis of isothiocyanates from amines using di-tert-butyl dicarbonate. Tetrahedron Lett. 2008;49(19):3117-3119.

22. Shi Y, Zhang HB, Zong L. Novel mannosylated chitosan to target mannose receptors-synthesis and its characterization and cytotoxicity. Pharm Biotechnol. 2009:207-211.

23. Lin C, Zhong Z, Lok MV, et al. Novel bioreducible poly(amido amine) s for highly efficient gene delivery. Bioconjug Chem. 2007;18(1): $138-145$.

24. Kloeckner J, Wagner E, Ogris M. Degradable gene carriers based on oligomerized polyamines. Eur J Pharm Sci. 2006;29(5):414-425.

25. Tarcha PJ, Pelisek J, Merdan T, et al. Synthesis and characterization of chemically condensed oligoethylenimine containing beta-aminopropionamide linkages for siRNA delivery. Biomaterials. 2007;28(25): 3731-3740.

26. Park MR, Han KO, Han IK, et al. Degradable polyethyleniminealt-poly(ethylene glycol) copolymers as novel gene carriers. J Control Release. 2005;105(3):367-380. 
27. Mosmann T. Rapid colorimetric assay for cellular growth and survival: application to proliferation and cytotoxicity assays. J Immunol Methods. 1983;65(1-2):55-63.

28. Inaba $\mathrm{K}$, Inaba $\mathrm{M}$, Romani $\mathrm{N}$, et al. Generation of large numbers of dendritic cells from mouse bone marrow cultures supplemented with granulocyte/macrophage colony-stimulating factor. J Exp Med. 1992;176(6):1693-1702.

29. Diebold SS, Plank C, Cotten M, Wagner E, Zenke M. Mannose receptormediated gene delivery into antigen presenting dendritic cells. Somat Cell Mol Genet. 2002;27(1-6):65-74.

30. Ruponen M, Arkko S, Urtti A, Reinisalo M, Ranta VP. Intracellular DNA release and elimination correlate poorly with transgene expression after non-viral transfection. J Control Release. 2009;136(3):226-231.

31. Jilek S, Merkle HP, Walter E. DNA-loaded biodegradable microparticles as vaccine delivery systems and their interaction with dendritic cells. Adv Drug Deliv Rev. 2005;57(3):377-390.

32. Cella M, Sallusto F, Lanzavecchia A. Origin, maturation and antigen presenting function of dendritic cells. Curr Opin Immunol. 1997;9(1): $10-16$
33. Reddy ST, Swartz MA, Hubbell JA. Targeting dendritic cells with biomaterials: developing the next generation of vaccines. Trends Immunol. 2006;27(12):573-579.

34. Shortman K, Liu YJ. Mouse and human dendritic cell subtypes. Nat Rev Immunol. 2002;2(3):151-161.

35. Veeraswamy RK, Cella M, Colonna M, Unanue ER. Dendritic cells process and present antigens across a range of maturation states. J Immunol. 2003;170(11):5367-5372.

36. Yoshida M, Mata J, Babensee JE. Effect of poly(lactic-co-glycolic acid) contact on maturation of murine bone marrow-derived dendritic cells. J Biomed Mater Res A. 2007;80(1):7-12.

37. Tang R, Palumbo RN, Nagarajan L, Krogstad E, Wang C. Well-defined block copolymers for gene delivery to dendritic cells: probing the effect of polycation chain-length. J Control Release. 2010;142(2): 229-237.
International Journal of Nanomedicine

\section{Publish your work in this journal}

The International Journal of Nanomedicine is an international, peerreviewed journal focusing on the application of nanotechnology in diagnostics, therapeutics, and drug delivery systems throughout the biomedical field. This journal is indexed on PubMed Central, MedLine, CAS, SciSearch $\AA$, Current Contents ${ }^{\circledR} /$ Clinical Medicine,

\section{Dovepress}

Journal Citation Reports/Science Edition, EMBase, Scopus and the Elsevier Bibliographic databases. The manuscript management system is completely online and includes a very quick and fair peer-review system, which is all easy to use. Visit http://www.dovepress.com/ testimonials.php to read real quotes from published authors. 